\title{
Nutritional Habits According to Human Chronotype and Nutritional Status of Morningness and Eveningness
}

\author{
Neşe Toktaş ${ }^{1}$, K. Alparslan Erman ${ }^{1}$, Zekai Mert ${ }^{1}$ \\ ${ }^{1}$ Akdeniz University, Sports Science Faculty, Antalya, Turkey \\ Correspondence: Neşe Toktaş, Akdeniz University, Sports Science Faculty, Antalya, Turkey.
}

Received: December 3, 2017

Accepted: January 24, 2018

Online Published: April 1, 2018

doi:10.11114/jets.v6i3a.3159

URL: https://doi.org/10.11114/jets.v6i3a.3159

\begin{abstract}
Sixty one female and eighty one male volunteers participated in the study that aims to assess the nutrition habits according to human chronotype and nutritional status of morningness and eveningness. Chronotype was assessed by Turkish version of the Morningness-Eveningness Questionnaire and the other questionnaire prepared to assess of nutritional habits of participants were used. Furthermore a three-day food record for assessment of nutritional status was completed by twelve male who were definite morning/moderate morning types and eleven male who were definite evening/moderate evening types. According to a three-day food record intake of daily total energy (kkal), fat (g) and carbohydrates (g) were higher and intake of protein (\% energy) was lower in the evening types $(\mathrm{p}<0,05)$. In conclusion, evening chronotype was associated with inadequate dietary habits and status such as high daily energy (kkal), fat (g) and carbohydrates (g) intakes and low protein intake (\% energy) and skipped meal.
\end{abstract}

Keywords: chronotype, nutrition habits, nutritional status

\section{Introduction}

Circadian rhythm (meaning 'about day') with a Latin root of circa dies is an basic biological process organizing the organism against predictable changes existing in almost all living organisms and occurring during the 24-hour process in the environment (Summa \& Turek, 2014). Chronotype is the expression of circadian rhythmicity in an individual, and chronotype is categorized under three categories. These are morning types, evening types and intermediate types (Vitale \& Weydahl, 2017). Morningness-Eveningness reflects personal differences in the circadian rhythms of various biological and psychological processes (Prieto et al., 2012). Morningness-Eveningness is the characteristic that indicates which time of the day the person prefers for rest and activity (Haraszti et al., 2014). Although circadian preference has a strong genetic and biological basis, it varies according to some sociodemographic characteristics, as sex and age (Tonetti et al., 2015). While morning types go to bed early, wake up early and show the best performance during the early hours of the day, evening types prefer to go to bed late and wake up late when compared to morning types. They mentally and physically show the best performance in the afternoon and during the evening hours (Tonetti et al., 2015). In general, there are intermediate types in the population. Definite morning or definite evening types are rare (Haraszti et al., 2014).

In the studies, chronotype is generally evaluated with valid and reliable scales such as the Morningness-Eveningness Questionnaire (Kanerva et al., 2012). According to the studies, disorders in the sleep-wake cycle and circadian adjustment may cause metabolic dysfunctions. Moreover, chronotype may affect mood, substance use (cigarette, alcohol, drugs), psychological problems, personality and academic performance, and eating behaviours. Hormonal changes and psychological characteristics may cause an increase in hunger and fatigue and increase the risk of obesity. There are studies indicating relationships between short sleep duration and unhealthy nutritional habits (Kanerva et al., 2012).

It is indicated in the studies that evening types have unhealthier nutritional habits when compared to morning types, they consume more macronutrients with higher energy after $8 \mathrm{pm}$, their meal times change, and they have unhealthy life style habits. It is also indicated in the studies that there is a positive relationship between abnormal circadian rhythm and diseases such as obesity, metabolic syndrome, cancer, cardiovascular diseases, asthma, type 2 diabetes (Maukonen et al., 2016; Maukonen et al., 2017; Mota et al., 2016; Sato-Mito et al., 2011a). However, the relationship among circadian rhythm, nutrition and obesity is unclear (Maukonen et al., 2016). 
The aim of this study is to identify nutritional habits according to the chronotypes of the students studying at Akdeniz University and to evaluate the nutritional status of morning type and evening type male students whose food consumption reports have been recorded.

\section{Methods}

\subsection{Participants}

The study was conducted between January 2017 and May 2017. 61 females and 81 males, in total 142 individuals studying at Akdeniz University participated in the study. Individuals with any health problems such as psychiatric diseases, respiratory diseases, etc. that can affect sleep duration and quality, who use drugs, consume foods and drinks with the high amount of caffeine such as tea, coffee, energy drinks, etc. were not included in the study. Chronotype was assessed by the Turkish version of the Morningness-Eveningness Questionnaire (MEQ). Individuals were also categorized as being evening type (score:16-41), intermediate type (42-58) or morning type (score: 59-86) (Mota et al., 2016). The nutritional habits of the individuals were determined by using the questionnaire form prepared by the researcher. Furthermore, three-day food consumption was obtained from 12 morning-type and 11 evening-type male individuals to identify their nutritional status.

\subsection{Measurement Instruments}

\subsubsection{Chronotype}

Chronotype was evaluated using MEQ developed by Horne and Ostberg and adapted into Turkish by Pündük et al. (2005). Morningness-eveningness is expressed by a score that ranges from 16 to 86 , low scores indicating eveningness and high scores, morningness. Individuals were also categorized as being evening type (score:16-41), intermediate type (42-58) or morning type (score: 59-86) in study (Mota et al., 2016) .

\subsubsection{Nutritional Habits}

A questionnaire form prepared by the researcher and consisting of 12 questions was applied to the individuals to determine descriptive information such as age, gender, anthropometric measurement information, nutritional habits, consumption frequency of fast-food, and water consumption amount.

\subsubsection{Nutritional Status}

Food records were filled in for three non-consecutive days (two weekdays and one weekend day) and dietary recall forms were processed by a specialized dietitian. A nutrition software program ("Ebispro for Windows, Stuttgart, Germany; Turkish version BeBiS; Data Bases: Bundeslebens-mittelschlüssell, 11.3 and other sources") that contains information on 20,000 foods and beverages was used to calculate the mean daily intakes of energy and nutrients (protein, fat, carbohydrate).

\subsubsection{Statistical Analysis}

Descriptive statistical methods were used for the evaluation process of the data and one-way ANOVA or Kruskal-Wallis test was conducted to find out body mass index and water consumption according to chronotypes. And also according to three-day food record, unpaired $t$ test or Mann Whitney $U$ test was used to compare the results of macro nutrient intakes of individuals.

\section{Results}

Sixty one female (age: $22,06 \pm 2,61$ years, height: $165,18 \pm 6,51 \mathrm{~cm}$, body mass: $57,44 \pm 9,59 \mathrm{~kg}$ ) and eighty one male volunteers (age: $21,66 \pm 2,18$ years, height: $178,56 \pm 7,12 \mathrm{~cm}$, body mass: $75,46 \pm 11,54 \mathrm{~kg}$ ) participated in the study that aims to assess the nutrition habits according to human chronotype and nutritional status of morningness and eveningness (table 1).

Table 1. Subjects Characteristics

\begin{tabular}{llll}
\hline & $\begin{array}{l}\text { Female }(\mathbf{n = 6 1}) \\
(\text { Mean}) \text { SD }\end{array}$ & $\begin{array}{l}\text { Male }(\mathbf{n = 8 1}) \\
\text { (Mean) SD }\end{array}$ & $\begin{array}{l}\text { Total }(\mathbf{n = 1 4 2}) \\
(\text { Mean }) \text { SD }\end{array}$ \\
\hline Age (yıl) & $22,06 \pm 2,61$ & $21,66 \pm 2,18$ & $21,83 \pm 2,37$ \\
Height $(\mathrm{cm})$ & $165,18 \pm 6,51$ & $178,56 \pm 7,12$ & $67,72 \pm 13,96$ \\
Weight $(\mathrm{kg})$ & $57,44 \pm 9,59$ & $75,46 \pm 11,54$ & $68,89 \pm 8,96$ \\
\hline
\end{tabular}

In this study, 2,8\% of the participants were definite morning types, $9,9 \%$ were moderate morning types, $62,7 \%$ were intermediate types, 22,5\% were moderate evening types, 2,1\% were definite evening types. Individuals were classified as morning, evening and intermediate types (table 2). 
Table 2. The Distribution of Morning and Evening Types in Human Circadian Rhythm in Terms of Gender

\begin{tabular}{|c|c|c|c|c|c|c|c|c|}
\hline & & \multicolumn{3}{|c|}{ Female $(n=61)$} & \multicolumn{2}{|c|}{ Male $(n=81)$} & \multicolumn{2}{|c|}{ Total $(n=142)$} \\
\hline \multirow{3}{*}{ 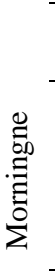 } & $\begin{array}{l}\text { Morningness-eveningness } \\
(\mathrm{n}=104)\end{array}$ & type & $\mathbf{f}$ & $\%$ & f & $\%$ & $\mathbf{f}$ & $\%$ \\
\hline & Definite morning types & & 0 & 0,0 & 4 & 4,9 & 4 & 2,8 \\
\hline & Moderate morning types & & 6 & 9,8 & 8 & 9,9 & 14 & 9,9 \\
\hline & Intermediate types & & 42 & 68,9 & 47 & 58,0 & 89 & 62,7 \\
\hline$\tilde{s}$ & Moderate evening types & & 13 & 21,3 & 19 & 23,5 & 32 & 22,5 \\
\hline 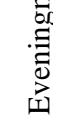 & Definite evening types & & 0 & 0,0 & 3 & 3,7 & 3 & 2,1 \\
\hline
\end{tabular}

While $11.1 \%$ of morning-type individuals do not skip a meal, $14.6 \%$ of intermediate-type individuals do. Moreover, all of the evening-type individuals skip a meal. The most frequently skipped meal is breakfast in all three groups (33.33\% of the morning type, $60.00 \%$ of the evening type, $44.9 \%$ of the intermediate type). Most of the morning-type (56.3\%) and evening-type (40.0\%) individuals skip a meal because they forget/cannot find an opportunity and a large part of the intermediate-type individuals skip a meal because they do not feel like it. Most of the morning types (69.2\%), evening types $(50.0 \%)$ and intermediate types $(77.3 \%$ ) have breakfast at home. While $53.3 \%$ of the morning types and $65.2 \%$ of the intermediate types have lunch at the school cafeteria, $54.2 \%$ of the evening types prefer fast-food companies. Most of the morning-type (93.8\%), evening-type (71.0\%) and intermediate-type (84.3\%) individuals have dinner at home. 5.6\% of the morning-type, $14.3 \%$ of the evening-type and $9.0 \%$ of the intermediate-type individuals stated that they consume fast-food and beverages every day (Table 3 ).

Table.3. Nutritional Habits According to Circadian Rhythm Types

\begin{tabular}{|c|c|c|c|c|c|c|}
\hline & \multicolumn{2}{|c|}{ Morningness $(\mathrm{n}=18)$} & \multicolumn{2}{|c|}{ Eveningness $(\mathrm{n}=\mathbf{3 5})$} & \multicolumn{2}{|c|}{ Intermediate $(\mathrm{n}=89)$} \\
\hline Skipping Meals & $\mathbf{f}$ & $\%$ & $\mathbf{f}$ & $\%$ & $\mathbf{f}$ & $\%$ \\
\hline Not skipped & 2 & 11,1 & 0 & 0,0 & 13 & 14,6 \\
\hline Morning & 6 & 33,3 & 21 & 60,0 & 40 & 44,9 \\
\hline Lunch & 2 & 11,1 & 6 & 17,1 & 15 & 16,9 \\
\hline Morning-Lunch & 1 & 5,6 & 4 & 11,4 & 5 & 5,6 \\
\hline Dinner & 2 & 11,1 & 2 & 5,7 & 5 & 5,6 \\
\hline Break & 5 & 27,8 & 2 & 5,7 & 11 & 12,4 \\
\hline \multicolumn{7}{|c|}{ The reasons of skipping meal } \\
\hline Weight loss & 1 & 6,3 & 1 & 2,9 & 2 & 2,6 \\
\hline Feel disinclined & 2 & 12,5 & 12 & 34,3 & 32 & 42,1 \\
\hline Forgetting/lack of time & 9 & 56,3 & 14 & 40,0 & 29 & 38,2 \\
\hline Not in the habit & 4 & 25,0 & 8 & 22,9 & 13 & 17,1 \\
\hline \multicolumn{7}{|l|}{ Usually breakfast place } \\
\hline Home & 9 & 69,2 & 5 & 50,0 & 34 & 77,3 \\
\hline School & 2 & 15,4 & 3 & 30,0 & 7 & 15,9 \\
\hline Fast food restaurant & 0 & 0,0 & 2 & 20,0 & 1 & 2,3 \\
\hline Dormitory & 2 & 15,4 & 0 & 0,0 & 2 & 4,5 \\
\hline \multicolumn{7}{|l|}{ Usually lunch place } \\
\hline Home & 1 & 6,7 & 2 & 8,3 & 7 & 10,1 \\
\hline School dining hall & 8 & 53,3 & 7 & 29,2 & 45 & 65,2 \\
\hline Home made & 0 & 0,0 & 2 & 8,3 & 5 & 7,2 \\
\hline Fast food restaurant & 4 & 26,7 & 13 & 54,2 & 10 & 14,5 \\
\hline Restaurant & 2 & 13,3 & 0 & 0,0 & 1 & 1,4 \\
\hline Dormitory & 0 & 0,0 & 0 & 0,0 & 1 & 1,4 \\
\hline \multicolumn{7}{|l|}{ Usually dinner place } \\
\hline Home & 1. & 93,8 & 22 & 71,0 & 70 & 84,3 \\
\hline School dining hall & 0 & 0,0 & 0 & 0,0 & 2 & 2,4 \\
\hline Home made & 0 & 0,0 & 0 & 0,0 & 3 & 3,6 \\
\hline Fast food restaurant & 0 & 0,0 & 5 & 16,1 & 5 & 6,0 \\
\hline Restaurant & 0 & 0,0 & 2 & 6,5 & 0 & 0,0 \\
\hline Dormitory & 1 & 6,3 & 2 & 6,5 & 3 & 3,6 \\
\hline \multicolumn{7}{|l|}{ Fast food frequency } \\
\hline Everyday & 1 & 5,6 & 5 & 14,3 & 8 & 9,0 \\
\hline 1-2 times a week & 5 & 27,8 & 10 & 28,6 & 32 & 36,0 \\
\hline 3-4 times a week & 7 & 38,9 & 15 & 48,6 & 19 & 21,3 \\
\hline Once every 15 days & 2 & 11,1 & 1 & 2,9 & 12 & 13,5 \\
\hline Once a month & 3 & 16,7 & 2 & 5,7 & 16 & 18,0 \\
\hline Never & 0 & 0,0 & 0 & 0,0 & 2 & 2,2 \\
\hline
\end{tabular}


As indicated in Table 4, there is no significant difference among morning-type, evening-type and intermediate-type individuals in terms of the body mass index and water consumption amount $(\mathrm{p}>0.05)$.

Table 4. Body Mass Index and Water Consumption Amount According to Circadian Rhythm Types

\begin{tabular}{lllll}
\hline & $\begin{array}{l}\text { Morningness }(\mathbf{n}=18) \\
\text { (Mean) SD }\end{array}$ & $\begin{array}{l}\text { Eveningness }(\mathbf{n}=35) \\
\text { (Mean) SD }\end{array}$ & $\begin{array}{l}\text { Intermediate (n=89) } \\
\text { (Mean) SD }\end{array}$ & \\
\hline Body mass index $\left(\mathrm{kg} / \mathrm{m}^{2}\right)$ & $22,69 \pm 2,83$ & $22,76 \pm 3,22$ & $22,30 \pm 2,90$ & $\begin{array}{l}\mathrm{F}=0,36 \\
\mathrm{p}=0,70\end{array}$ \\
\hline Water Consumption & $2067,65 \pm 955,07$ & $1461,18 \pm 795,54$ & $1813,07 \pm 995,08$ & $\begin{array}{l}\chi^{2}=4,93 \\
\mathrm{sd}=2 \\
\mathrm{p}=0,08\end{array}$ \\
\hline
\end{tabular}

According to the data of the three-day food consumption form obtained from 12 morning type and 11 evening type male individuals, while the energy amount ( $\mathrm{kcal})$, fat content $(\mathrm{g})$ and carbohydrate amount $(\mathrm{g})$ that evening-type individuals obtain from food are higher when compared to morning-type individuals, the percentage rate of daily consumed energy obtained from protein is lower in evening-type individuals $(\mathrm{p}<0.05)$. There is no difference among the daily consumed protein, the percentage rate of energy obtained from carbohydrate and fat, fiber $(\mathrm{g})$, cholesterol $(\mathrm{mg})$, vitamin A $(\mu \mathrm{g})$, vitamin E, $\mathrm{B}_{1}, \mathrm{~B}_{2}, \mathrm{~B}_{6}, \mathrm{C}(\mathrm{mg})$, sodium (mg), potassium (mg), calcium (mg), magnesium (mg), phosphor (mg), iron (mg) and zinc (mg) intakes of morning-type and evening-type male individuals ( $p>0,05)$. (table 5).

Moreover, there is no difference between the BMIs of morning-type (BMI: $22.60 \pm 2.41 \mathrm{~kg} / \mathrm{m}^{2}$ ) and evening-type (BMI: $22.09 \pm 1.83 \mathrm{~kg} / \mathrm{m}^{2}$ ) male individuals $(\mathrm{p}>0.05)$.

Table 5. Nutritional Status Determined with Three-Day Food Consumption in Morning and Evening-Type Male Individuals

\begin{tabular}{|c|c|c|c|}
\hline & $\begin{array}{l}\text { Morningness }(\mathbf{n}=12) \\
\text { (Mean) SD }\end{array}$ & $\begin{array}{l}\text { Eveningness }(\mathbf{n}=11) \\
\text { (Mean) SD }\end{array}$ & \\
\hline Energy (kkal) & $1723,54 \pm 543,28$ & $2450,42 \pm 625,02$ & $\begin{array}{l}\mathrm{t}=-2,92 \\
\mathrm{p}=0,00^{*}\end{array}$ \\
\hline Protein $(\mathrm{g})$ & $64,27 \pm 20,89$ & $73,09 \pm 26,51$ & $\begin{array}{l}\mathrm{t}=-0,87 \\
\mathrm{p}=0,39\end{array}$ \\
\hline Protein $(\%)$ & $15,58 \pm 2,84$ & $12,50 \pm 3,81$ & $\begin{array}{l}\mathrm{t}=2,17 \\
\mathrm{p}=0,04^{*}\end{array}$ \\
\hline Carbohydrate (g) & $198,14 \pm 81,71$ & $301,72 \pm 105,38$ & $\begin{array}{l}\mathrm{z}=-2,31 \\
\mathrm{p}=0,02 *\end{array}$ \\
\hline Carbohydrate $(\%)$ & $46,67 \pm 7,32$ & $50,80 \pm 8,47$ & $\begin{array}{l}\mathrm{t}=-1,23 \\
\mathrm{p}=0,23\end{array}$ \\
\hline Fat $(\mathrm{g})$ & $69,69 \pm 18,95$ & $99,32 \pm 26,73$ & $\begin{array}{l}\mathrm{t}=-3,03 \\
\mathrm{p}=0,00^{*}\end{array}$ \\
\hline Fat $(\%)$ & $37,67 \pm 7,51$ & $36,70 \pm 7,02$ & $\begin{array}{l}t=0,30 \\
p=0,76\end{array}$ \\
\hline Fiber $(\mathrm{g})$ & $17,09 \pm 7,39$ & $20,89 \pm 5,82$ & $\begin{array}{l}\mathrm{t}=-1,32 \\
\mathrm{p}=0,20\end{array}$ \\
\hline Cholesterol(mg) & $357,01 \pm 163,11$ & $312,00 \pm 237,69$ & $\begin{array}{l}t=0,53 \\
p=0,61\end{array}$ \\
\hline Vit A $(\mu \mathrm{g})$ & $1258,29 \pm 996,69$ & $1322,33 \pm 1993,31$ & $\begin{array}{l}t=-0,09 \\
p=0,92\end{array}$ \\
\hline Vit E (mg) & $17,53 \pm 7,13$ & $19,72 \pm 5,67$ & $\begin{array}{l}\mathrm{t}=-0,79 \\
\mathrm{p}=0,44\end{array}$ \\
\hline Vit $B_{1}(\mathrm{mg})$ & $0,72 \pm 0,37$ & $0,85 \pm 0,21$ & $\begin{array}{l}\mathrm{t}=-0,93 \\
\mathrm{p}=0,37\end{array}$ \\
\hline Vit $B_{2}(\mathrm{mg})$ & $1,17 \pm 0,34$ & $1,38 \pm 0,58$ & $\begin{array}{l}t=-1,07 \\
p=0,30\end{array}$ \\
\hline Vit $\mathrm{B}_{6}(\mathrm{mg})$ & $1,18 \pm 0,45$ & $1,46 \pm 0,36$ & $\begin{array}{l}t=-1,62 \\
p=0,12\end{array}$ \\
\hline Vit C (mg) & $66,55 \pm 39,88$ & $57,55 \pm 22,64$ & $\begin{array}{l}t=0,63 \\
p=0,53\end{array}$ \\
\hline Sodium (mg) & $3294,87 \pm 1047,36$ & $4214,90 \pm 1553,86$ & $\begin{array}{l}t=-1,65 \\
p=0,11\end{array}$ \\
\hline Potassium (mg) & $1911,88 \pm 673,05$ & $2309,71 \pm 551,95$ & $\begin{array}{l}\mathrm{t}=-1,49 \\
\mathrm{p}=0,15\end{array}$ \\
\hline Calcium (mg) & $532,83 \pm 223,39$ & $646,95 \pm 210,86$ & $\begin{array}{l}t=-1,22 \\
p=0,23\end{array}$ \\
\hline Magnesium (mg) & $214,73 \pm 71,40$ & $268,89 \pm 70,26$ & $\begin{array}{l}\mathrm{t}=-1,79 \\
\mathrm{p}=0,09\end{array}$ \\
\hline Phosphor (mg) & $987,93 \pm 333,53$ & $1166,46 \pm 345,62$ & $\begin{array}{l}t=-1,23 \\
p=0,23\end{array}$ \\
\hline Iron (mg) & $9,90 \pm 2,98$ & $11,72 \pm 3,10$ & $\begin{array}{l}\mathrm{t}=-1,40 \\
\mathrm{p}=0,18\end{array}$ \\
\hline Zinc (mg) & $8,86 \pm 3,25$ & $10,30 \pm 3,79$ & $\begin{array}{l}\mathrm{t}=-0,93 \\
\mathrm{p}=0,35\end{array}$ \\
\hline
\end{tabular}




\section{Discussion}

In the study conducted to determine the nutritional habits of the students studying at Akdeniz University according to their chronotype and to evaluate the nutritional status of morning-type and evening-type male students whose food consumption has been recorded, while $11.1 \%$ of the morning-type individuals do not skip meal, $14.6 \%$ of the intermediate-type individuals do not skip meal. Moreover, all of the evening-type individuals skip a meal. The most frequently skipped meal is breakfast in all three groups (33.33\% of the morning type, $60.00 \%$ of the evening type, $44.9 \%$ of the intermediate type). $5.6 \%$ of the morning-type individuals, $14.3 \%$ of the evening-type individuals and $9.0 \%$ of the intermediate type individuals stated that they consume fast-food and beverages every day.

The studies indicate that evening types have different nutritional habits such as skipping breakfast, consuming food in bigger portions, consuming foods of low quality (Mota et al., 2016). In the study conducted on 800 Japanese female students between the ages of 18-29 years, the MEQ score was found to be positively related to breakfast consumption frequency (Nakade et al., 2009). In another study conducted on 197 females, 138 males, in total 335 students, evening types are inclined to skip breakfast and consume more fast-food (Schubert \& Randler, 2008). In a study conducted on 152 female and male students, morning types consumed less fast-food (Fleig \& Randler, 2009). In a study conducted on 1854 individuals between the ages of 25-74 years, it is stated that evening types have irregular meal times (Maukonen et al., 2017)

In our study, there is no significant difference among morning-type, evening-type and intermediate-type individuals in terms of the body mass index and water consumption amount. According to the data of the three-day food consumption form obtained from 12 morning-type and 11 evening-type male individuals, while the energy amount (kcal), fat content (g) and carbohydrate amount (g) that evening-type individuals obtain from food are higher when compared to morning-type individuals, the percentage rate of daily consumed energy obtained from protein is lower in evening-type individuals. There is no difference among the daily consumed protein, the percentage rate of energy obtained from carbohydrate and fat, fiber $(\mathrm{g})$, cholesterol $(\mathrm{mg})$, vitamin $\mathrm{A}(\mu \mathrm{g})$, vitamin $\mathrm{E}, \mathrm{B}_{1}, \mathrm{~B}_{2}, \mathrm{~B}_{6}, \mathrm{C}(\mathrm{mg})$, sodium $(\mathrm{mg})$, potassium $(\mathrm{mg})$, calcium $(\mathrm{mg})$, magnesium $(\mathrm{mg})$, phosphor $(\mathrm{mg})$, iron $(\mathrm{mg})$ and zinc $(\mathrm{mg})$ intakes of morning-type and evening-type male individuals ( $>0.05)$. Moreover, there is no difference among the BMIs of morning-type and evening-type male individuals.

There are inconsistent results related to the relationship between obesity and chronotype in the studies. In the study conducted by Maukonen et al. (2016), BMI is not different according to the chronotypes. Arora and Taheri (2015) found in the study they conducted on 511 adolescents between the ages of 11-13 years that evening chronotypes have higher BMI when compared to definite morning chronotypes. In the study conducted on 4493 individuals between the ages of 25-74 years, no relationship was found between BMI and energy consumption, and the ME score (Kanerva et al., 2012). In our study, while the energy amount (kcal), fat content $(\mathrm{g})$ and carbohydrate amount $(\mathrm{g})$ that evening-type individuals among male individuals whose food consumption has been recorded obtain from food are higher when compared to morning-type individuals, although the percentage rate of daily consumed energy obtained from protein is lower in evening-type individuals, there is no difference between their BMIs. The BMIs of the evening types are not high. One of the explanations for this situation is that the individuals are at a young age (There may be an increase in gaining weight with age). Another explanation and one of the limitations of the study may be that there are no records of physical activity.

Previous studies indicate that evening types consume unhealthy food and nutrients, consume more beverages, alcohol and chocolate, take more fat and saturated fat, consume less carbohydrate, pulp, vegetables, fruit and fish and their diet quality is low (Baron et al., 2011; Haraszti et al., 2014; Kanerva et al., 2012; Maukonen et al., 2016; Sato-Mito et al., 2011b).

A study, in which the relationship between the chronotype, and food groups and nutrient intake in Japan was examined, was conducted on 3304 female dietetic students between the ages of 18-20 years. A negative relationship was found between the late midpoint of sleep (The midpoint of sleep was calculated using self-reported bedtimes and risetimes) and the percentage of the total daily energy obtained from carbohydrate and protein, cholesterol, potassium, calcium, magnesium, iron, zinc, vitamin $\mathrm{A}$ and $\mathrm{D}$, thiamin, riboflavin, vitamin $\mathrm{B}_{6}$, folate, rice, vegetables, eggs, dairy products, legumes, and a positive relationship was determined among the percentage of energy obtained from alcohol and fat, noodle, candy, fat and oil and meat consumption (Sato-Mito et al., 2011b). In another study conducted on 112 young Japanese women, in which the relationship between chronotype and food intake was examined, evening tendency was found to be related to lower protein, calcium, magnesium, zinc, vitamin D, riboflavin, vitamin B6 and vegetable intake and more noodle intake. Energy consumption and BMI are not different according to the MEQ score (Sato-Mito et al., 2011a). In a study in which the relationship between energy and macronutrient intake time, and chronotype was examined, the total energy intake is not different according to the chronotype. However, while evening types take less 
energy and nutrient in the morning (before $10 \mathrm{AM}$ ) when compared to morning types, they take more energy and macronutrients in the evening (after 8 PM) (meal time was not questioned in our study). In a study conducted on 1854 individuals between the ages of 25-74 years, protein intakes of evening types were found to be lower in terms of macronutrients. Evening types take more sucrose, fat and saturated fat during evening hours (Maukonen et al., 2017). In a study in which the relationship between food intake and chronotype was examined, a negative relationship was found between the chronotype score, and energy, carbohydrate, protein, cholesterol and sweet consumption (Mota et al., 2016).

Maukonen et al. (2016) have stated that although evening types are less inclined to a healthy diet, there is no evidence that chronotype will modify the relationship between obesity and healthy diet. In this study, no difference was found among the chronotypes in terms of energy consumption.

It is stated that Social jet lag may be one of the mechanisms for the evening types to be more inclined to unhealthy diet when compared to other chronotypes. Social jet lag is likely to have an effect on food consumption along with other lifestyle factors. The other mechanism may be different personal characteristics among the chronotypes. Evening types are less conscientious and have less self-control (Maukonen et al., 2016). Evening types also have unhealthy behaviours such as smoking, physical inactivity in addition to an unhealthy diet (Haraszti et al., 2014; Nakade et al., 2009; Urban et al., 2011).

For example, in a study conducted on 4493 individuals between the ages of 25-74 years, most of the evening types are physically inactive (Kanerva et al., 2012). It is indicated that short term sleep deprivation, which evening types are inclined to, decreases physical activity (Schmid et al., 2009). A decrease in physical activity, watching television or using a computer, keeping late hours and irregular schedule affect the food consumption of evening types. Depressive symptoms may affect food consumption (Kanerva et al., 2012).

It is stated in the studies that leptin, cortisol, insulin, thyroid stimulating hormone and other parameters are affected by short sleep duration, short sleep duration causes changes in hormones related to appetite and it especially increases hunger and appetite for foods with high carbohydrate and calories (Kanerva et al., 2012; Nguyen \& Wright, 2009; Sato-Mito et al., 2011b; Scheer et al., 2009).

Although there are studies conducted on energy intake timing and obesity, BMI, further studies are required on the role of chronotype in this relationship (Maukonen et al., 2017).

The strengths of this study included a random sample, and chronotype was assessed using a validated method. There are some limitations in the present research. Since the number of samples is low, it did not include a population-based approach. Also, dietary intakes and the assessment of chronotype were based only on self-reported data. In this study, food consumption frequency, sleep duration and physical activities were not recorded. Further studies with larger populations are necessary to better understand the relationship between chronotype and nutrition.

\section{References}

Arora, T., \& Taheri, S. (2015). Associations among late chronotype, body mass index and dietary behaviors in young adolescents. International Journal of Obesity, 39(1), 39. https://doi.org/10.1038/ijo.2014.157

Baron, K. G., Reid, K. J., Kern, A. S., \& Zee, P. C. (2011). Role of sleep timing in caloric intake and BMI. Obesity, 19(7), 1374-1381. https://doi.org/10.1038/oby.2011.100

Fleig, D., \& Randler, C. (2009). Association between chronotype and diet in adolescents based on food logs. Eating Behaviors, 10(2), 115-118. https://doi.org/10.1016/j.eatbeh.2009.03.002

Haraszti, R. A., Purebl, G., Salavecz, G., Poole, L., Dockray, S., \& Steptoe, A. (2014). Morningness-eveningness interferes with perceived health, physical activity, diet and stress levels in working women: A cross-sectional study. Chronobiology International, 31(7), 829-837. https://doi.org/10.3109/07420528.2014.911188

Kanerva, N., Kronholm, E., Partonen, T., Ovaskainen, M. L., Kaartinen, N. E., Konttinen, H., ... Männistö, S. (2012). Tendency toward eveningness is associated with unhealthy dietary habits. Chronobiology International, 29(7), 920-927. https://doi.org/10.3109/07420528.2012.699128

Maukonen, M., Kanerva, N., Partonen, T., Kronholm, E., Konttinen, H., Wennman, H., \& Männistö, S. (2016). The associations between chronotype, a healthy diet and obesity. Chronobiology International, 33(8), 972-981. https://doi.org/10.1080/07420528.2016.1183022

Maukonen, M., Kanerva, N., Partonen, T., Kronholm, E., Tapanainen, H., Kontto, J., \& Männistö, S. (2017). Chronotype differences in timing of energy and macronutrient intakes: A population-based study in adults. Obesity, 25(3), 608-615. https://doi.org/10.1002/oby.21747 
Mota, M. C., Waterhouse, J., De-Souza, D. A., Rossato, L. T., Silva, C. M., Araújo, M. B. J., ... Crispim, C. A. (2016). Association between chronotype, food intake and physical activity in medical residents. Chronobiology International, 33(6), 730-739. https://doi.org/10.3109/07420528.2016.1167711

Nakade, M., Takeuchi, H., Kurotani, M., \& Harada, T. (2009). Effects of meal habits and alcohol/cigarette consumption on morningness-eveningness preference and sleep habits by Japanese female students aged 18-29. Journal of Physiological Anthropology, 28(2), 83-90. https://doi.org/10.2114/jpa2.28.83

Nguyen, J., \& Wright Jr, K. P. (2009). Influence of weeks of circadian misalignment on leptin levels. Nature and Science of Sleep, 2010(2), 9.

Prieto, P. D., Díaz-Morales, J. F., Barreno, C. E., Mateo, M. J. C., \& Randler, C. (2012). Morningness-eveningness and health-related quality of life among adolescents. The Spanish Journal of Psychology, 15(2), 613-623. https://doi.org/10.5209/rev_SJOP.2012.v15.n2.38872

Punduk, Z., Gur, H., \& Ercan, I. (2005). A reliability study of the Turkish version of the morningness-eveningness questionnaire. Turkish Journal of Psychiatry, 16(1), 1-6.

Sato-Mito, N., Sasaki, S., Murakami, K., Okubo, H., Takahashi, Y., Shibata, S., ... Freshmen in Dietetic Courses Study II group. (2011b). The midpoint of sleep is associated with dietary intake and dietary behavior among young Japanese women. Sleep Medicine, 12(3), 289-294. https://doi.org/10.1016/j.sleep.2010.09.012

Sato-Mito, N., Shibata, S., Sasaki, S., \& Sato, K. (2011a). Dietary intake is associated with human chronotype as assessed by both morningness-eveningness score and preferred midpoint of sleep in young Japanese women. International Journal of Food Sciences and Nutrition, 62(5), 525-532. https://doi.org/10.3109/09637486.2011.560563

Scheer, F. A., Hilton, M. F., Mantzoros, C. S., \& Shea, S. A. (2009). Adverse metabolic and cardiovascular consequences of circadian misalignment. Proceedings of the National Academy of Sciences, 106(11), 4453-4458. https://doi.org/10.1073/pnas.0808180106

Schmid, S. M., Hallschmid, M., Jauch-Chara, K., Wilms, B., Benedict, C., Lehnert, H., ... Schultes, B. (2009). Short-term sleep loss decreases physical activity under free-living conditions but does not increase food intake under time-deprived laboratory conditions in healthy men. The American Journal of Clinical Nutrition, 90(6), 1476-1482. https://doi.org/10.3945/ajcn.2009.27984

Schubert, E., \& Randler, C. (2008). Association between chronotype and the constructs of the Three-Factor-Eating-Questionnaire. Appetite, 51(3), 501-505. https://doi.org/10.1016/j.appet.2008.03.018

Summa, K. C., \& Turek, F. W. (2014). Chronobiology and obesity: interactions between circadian rhythms and energy regulation. Advances in Nutrition: An International Review Journal,5(3), 312S-319S. https://doi.org/10.3945/an.113.005132

Tonetti, L., Natale, V., \& Randler, C. (2015). Association between circadian preference and academic achievement: a systematic review and meta-analysis. Chronobiology International, 32(6), 792-801. https://doi.org/10.3109/07420528.2015.1049271

Urbán, R., Magyaródi, T., \& Rigó, A. (2011). Morningness-eveningness, chronotypes and health-impairing behaviors in adolescents. Chronobiology International, 28(3), 238-247. https://doi.org/10.3109/07420528.2010.549599

Vitale, J. A., \& Weydahl, A. (2017). Chronotype, Physical Activity, and Sport Performance: A Systematic Review. Sports Medicine, 1-10. https://doi.org/10.1007/s40279-017-0741-z

\section{Copyrights}

Copyright for this article is retained by the author(s), with first publication rights granted to the journal.

This is an open-access article distributed under the terms and conditions of the Creative Commons Attribution license which permits unrestricted use, distribution, and reproduction in any medium, provided the original work is properly cited. 